Snežana Dimitrijević ${ }^{*}$

Prima International School of Belgrade
371.3::811.134.2'243

https://doi.org/10.18485/

zivjez.2020.40.1.8

Оригинални научни рад

\title{
ABDUCTIVE REASONING AS A CONSEQUENCE OF TRANSLANGUAGING IN A MULTICULTURAL CONTEXT ${ }^{1}$
}

This paper represents a part of an exploratory study on the processes of abductive reasoning as a strategy in foreign language learning, with its possible applications for foreign language instruction. The specific purpose of the study is to explore students' usage of their plurilingual repertoires through their cognitive thinking system of hypothesis making.

Coming from the theory of foreign language acquisition and practice, the main study explores the concept of plurilingualism and investigates the ability of students to use their background knowledge (from mother tongue, second language/s, foreign language/s), and all their past experiences, in order to make conclusions and transform experience into usable information. It is assumed that acquisition of all kinds of knowledge and experiences leads to better anticipation and understanding. Thus, when the language learner is confronted with a new linguistic unit for the first time, he/she uses background information and generates a causal explanation.

Keywords: abductive reasoning, foreign language learning strategies, plurilingualism, translanguaging, anticipation, interlanguage inference.

\section{Introduction}

While languages are based on the organization of the form and the organization of the meaning, the way in which these two processes take place is arbitrary (Nation 2013). Depending on

\footnotetext{
* snezanadimitrijevic0@gmail.com

1 This paper is a part of a Ph.D. study in progress on abductive reasoning in foreign language learning at the University of Belgrade.
} 
the approach to the processing of linguistic material, it depends on what will be processed first, the form or the meaning (e.g. the communicative approach starts from the meaning to the form, the traditional from the form to the meaning).

According to the Dynamic System Theory (Garcia \& Wei 2014: 16-17), languages exist in contact with other languages. They are influenced by other languages and they contain shared structural elements. However, as discussed in Odlin (1989), the interlanguage inference is closely related to the process language transfer. Both interlanguage inferencing and language transfer participate in the process of the dynamic construction of interlanguage, a process that is considered central to most modern theories of language acquisition (Gass \& Selinker 1994: 7).

When Ringbom (2007) researched the impact of cross-linguistic similarity in foreign language learning, he pointed out that similarity in languages can be either in the form or in the meaning, namely function. In addition, he noted and emphasized that similarity in form significantly facilitates understanding, and concluded that the search for similarities is the basis of learning. There is a natural and spontaneous mechanism in the learning process that first involves establishing a relationship between the new item and the item we already have in mind. Ringbom pointed out that if establishing a relationship is not possible due to the absence of similarities, we move on to what is different. Abductive reasoning works in an identical way - we are searching for interlinguistic similarity, in our case between words.

In this paper we present the theoretical background underlying the study and show the result of an empirical research on students' capacity to infer the word meaning/form based on their overall linguistic knowledge, their knowledge of cultures, and world knowledge. There has been a prior investigation regarding abductive reasoning and Spanish language learning (Jovanović and Zečević Krneta 2012). Despite the difference between prior and our investigation, such as participants' backgrounds, their ages, language learning histories, and formal contexts, both studies explore individuals' access to abductive 
ABDUCTIVE REASONING AS A CONSEQUENCE OF TRANSLANGUAGING...

processes and suggest that the development and implementation of students' inference strategies should be addressed in educational practice.

\section{Translanguaging}

Translanguaging is the term coined by Cen Williams (1994; 1996): it referred to a pedagogical practice where students were asked to alternate languages for the purpose of either receptive or productive use (for example, students are asked to read in English and answer in Spanish). It relates to the Dynamic System Theory according to which languaging is being built in interaction between individuals and their environments (Herdina \& Jessner 2020). Namely, translanguaging is the fact of acting and languaging in our highly technological and globalized world. It does not refer to two separate languages nor to a synthesis of different language practice or to a hybrid mixture (Garcia \& Wei 2014: 32). Translanguaging refers to new language practices that reveal the complex language practices of plurilingual individuals in which they engage in order to make sense of their bi-/multilingual worlds, as well as pedagogical approaches that use those complex practices. The teacher who uses translanguaging becomes facilitator who set up the projectbased instruction and collaborative groupings in order to maximize interactions and enrich students' language.

\section{Abductive reasoning}

The term abduction was introduced into semiotic theory by the American philosopher, Charles Senders Pierce (1992, 1998). He was interested in the mental operation of guessing and viewed abduction as a process of "forming an explanatory hypothesis" (Thagard 2006: 200). Namely, there are three types of reasoning: deductive, inductive, and abductive. According to Pierce, the generation of scientific hypothesis is abduction that explains the result of the experiment and observation. Deduction and induction are, simply, phases of testing of an already created hypothesis. 


\subsection{Abductive reasoning and language learning}

Three types of reasoning are also discussed by Italian philosopher Umberto Eco (1984). According to Eco (Table 1), in deduction, the result is a consequence of the rule and the case. In induction, the result can be expected from a rule. Both induction and abduction involve uncertainty regarding the validity of the interlanguage inference as a whole to at least some degree. Abduction presupposes the knowledge of rules and it is crucial both from learning and teaching point of view (Berthele 2011).

Table 1. Linguistic unit DANZA taken from students' word recognition test represents three types of reasoning in the process of foreign language learning (adapted from Eco 1984: 42)

\begin{tabular}{|c|c|c|}
\hline DEDUCTION & INDUCTION & ABDUCTION \\
\hline RULE & RULE & $\begin{array}{c}\text { The knowledge of } \\
\text { RULE }\end{array}$ \\
\hline $\begin{array}{c}\text { English } \\
/ \mathrm{C} /=\text { Spanish/S/, /C/, } \\
/ \mathrm{Z} /\end{array}$ & $\begin{array}{c}\text { Interlinguistic } \\
\text { correspondence } \\
{[\mathrm{S}]=[\mathrm{S}],[\theta]} \\
\end{array}$ & $\begin{array}{c}\text { English /C/ and } \\
\text { Spanish /Z/ are } \\
\text { pronounced alike }\end{array}$ \\
\hline CASE & CASE & CASE \\
\hline $\begin{array}{l}\text { Spanish DANZA falls } \\
\text { under this rule }\end{array}$ & $\begin{array}{c}{[\mathrm{DANS}]-[\mathrm{DAN} \theta \mathrm{A}] \text { is a }} \\
\text { case like this }\end{array}$ & $\begin{array}{l}\text { I speculate that } \mathrm{Z} \text { in } \\
\text { DANZA is a case of a } \\
\text { general sound low }\end{array}$ \\
\hline RESULT & RESULT & RESULT \\
\hline DANZA=DANCE & $\begin{array}{l}\text { English DANCE } \\
\text { [DANS] English } \\
\text { [S] corresponds to } \\
\text { Spanish [S] or }[\theta]\end{array}$ & $\begin{array}{l}\text { DANZA reminds me of } \\
\text { DANCE... } \\
\text { The same case I have } \\
\text { in English TERRACE / } \\
\text { 'terəs / and Spanish } \\
\text { TERRAZA /terra } \theta \mathrm{a} /, \mathrm{I} \\
\text { conclude English C is } \\
\text { Spanish Z... }\end{array}$ \\
\hline
\end{tabular}


Similar to Pierce's explanation, Thagard (2006: 28) discusses abduction by referring to analogical inference: If object $X$ has properties A, B; and object $\mathrm{Y}$ has properties A, B; and object X has property $\mathrm{F}$, therefore object $\mathrm{Y}$ has property $\mathrm{F}$. This characterization of analogical inference is presented in Table 1 through the example of a potential grapheme-phoneme correspondence dance/danza: If the English grapheme has properties S, C; and Spanish grapheme has properties S, C; and English has property Z (as it is shown in spelling of the words terrace/terraza), thus the Spanish grapheme also has Z.

\subsection{Multilingualism and anticipation in adolescents}

Crucial for this study is our understanding of brain maturation during adolescence. There is evidence (Martínez 2016) to confirm that significant changes occur in behavioral, emotional, and cognitive development during the period of adolescence. Steinberg (2013) points to changes in cognition, or thinking, as one of the fundamental modifications of mental habits among adolescents. People start using hypothetical thinking in adolescence and this enables them to see beyond what is directly observable, to think about possibilities, and to anticipate what might be possible (Martínez 2016: 58). Adolescents are also able to make some decisions intuitively, taking advantage in this way of a wide range of experiences, including linguistic ones (Steinberg 2013: 56).

Martin Seligman, a researcher in prospection and related fields, suggests that anticipation is at the heart of effective learning:

Prospection is the mental process of projecting and evaluating future possibilities and then using these projections for guidance of thought and action. Like an old-time prospector searching for gold, the mind processes prospection maps out not just physical landscape lying ahead, but an array of possible paths through that landscape. (Seligman et al. 2016: 6)

In addition to prospection that represents a mental evaluation of possible future, all kinds of knowledge and all experiences are 
at the core of both mental operations - inferencing and abductive reasoning, as we have shown in the previous chapter. Nevertheless, theory of foreign language acquisition highlights that all knowledge and all linguistics experience contribute to the process of building communicative competence. In line with this, Council of Europe (2001: 4) defends that plurilingual approach should be emphasized due to the fact that all languages - whether learned at home, in school, or through immediate experience - as well as knowledge of cultures, are not kept in separate mental compartments of a person, but rather constantly take part in the creation of communicative competence. A plurilingual person, thus, uses different languages for different purposes, either separately or by mixing them (Cenoz 2013), instead of relying on one language for all possible situations. His/her language history and past experiences of languaging are required to anticipate and to form expectations in order to make new experiences.

Researchers recognize certain advantages that plurilinguals have over monolinguals in terms of learning new languages (Cummins 2000: 35). According to Cenoz (2003) plurilinguals are more experienced in language learning and they have developed learning skills and techniques. They are also able to apply different compensation strategies that help overcome problems in communication. Their metalinguistic awareness is at a high level as well as their communicative competence, especially pragmatic one (in assessing the appropriateness of statements on L3). In this context, a multilingual community, in a particularly dynamic school environment of an international school, represents the most suitable atmosphere for developing plurilingual mental repertoires.

\section{Methodology}

\subsection{Participants}

The International School of Belgrade is a multilingual and multicultural community that, currently, represents 45 nations. The multilingualism in the school, as diversity of foreign languages 
on offer, and strong support of mother tongue, goes beyond this and supports the plurilingual approach, which correlates with translanguaging method in language teaching and learning. The official school language is English.

The participants of this research study are the students of the Spanish language, from the school generation 2017/18 of the International School of Belgrade. The sample includes a total of thirty-four high school students, from fourteen to eighteen years of age, from various Spanish acquisition programs, from beginners to intermediate Spanish level.

Prior to the data collection, the students had completed the survey on language history and background. The results showed that students come from Armenia, Austria, Bulgaria, Canada, China, Croatia, Great Britain, Greece, France/Albania, Germany, Germany/ Australia, Israel, Italia, Moldavia, Norway, Poland, Russia, Serbia, South Korea, Sweden, United States of America, United States of America/Italy.

\subsection{Test description}

The data was collected through a recognition word test designed for the purpose of this study.

The instruction for the test explains the procedure for the students to follow: Write one translation which you consider most appropriate, next to each word. Additionally, the following is highlighted in red: it is important that you translate all words, to encourage students not to provide lucky responses, i.e. students are called to draw inferences and make a transfer based on their knowledge of Spanish and their knowledge of languages in general.

The word recognition test consists of two sections. Every section contains fifty items without the context: one to be translated from Spanish to English, other from English to Spanish. Thus, we assess both receptive and productive skills and we expect better outcomes for the English to Spanish word recognition test (Nation 2013: 72). 
The words in the recognition test are deliberately chosen, partially by the teacher, i.e. author of this study, partially selected from the list composed by Elective Spanish high school students (programme design to enhance the learning process of regular classes, generation 2016/17; see below). Several false cognates are added to the test from this list as a control to assess to what extent the students respond automatically without critical thinking.

In this way, we aimed to provide certain degree of students' familiarity with lexical items, but also, we wanted to encourage them to bring the whole of their linguistic and non-linguistic knowledge in order to make conclusions and to experiment with alternative forms of expressions. The goal is to prompt recognition of grapheme-phoneme correlation in students and to encourage them to anticipate and to try to infer meaning and form even if they are insecure.

\subsubsection{Multilingual Dictionary}

The elective students project titled Multilingual Dictionary reflects the complex language practices of multilingual individuals in the international school. The list is based on the theory of common international store (Council of Europe 2001: 4) and cognates recognition theory (Berthele 2011: 192-220). According to Ringbom (2007: 73), cognates are "historically related, formally similar words, whose meaning may be identical, similar, partly different, or, occasionally, even wholly different".

This Dictionary consists of 450 English, Spanish, German, French, Serbian, Italian and Korean lexical units (Latin, Cyrillic, and Korean letters). The project is inspired by the fact that unknown language and already learnt languages have the same or similar vocabulary (grapheme-phoneme correspondences) and this interlinguistic similarity can facilitate learning and communication. 
ABDUCTIVE REASONING AS A CONSEQUENCE OF TRANSLANGUAGING...

Table 2. Multilingual Dictionary, p. 9: Lexical units starting with letter D

\begin{tabular}{|c|c|c|c|c|c|c|}
\hline English & Español & German & French & Serbian & Italian & Korean \\
\hline culture & cultura & Kultur & culture & култура & cultorare & 문화 \\
\hline cure & curar & heilen & cure & лечити & cura & 약 \\
\hline cyclone & ciclón & Zyklon & cyclone & циклон & ciclone & 사이클론 \\
\hline dad & papá & Papa/Vater & papa & тата & papa & 아빠 \\
\hline dance & danza & tanzen & danse & плес & danza & 춤 \\
\hline declaration & declaración & Deklaration & déclaration & декларација & diclarazione & 선언 \\
\hline decorated & decorado & dekoriert & decoré & украшено & decorazione & 장식된 \\
\hline defense & defensa & Verteidigung & défense & одбрана & difensa & 방어 \\
\hline define & definir & definieren & définir & објаснити & definire & 정의하다 \\
\hline definitely & definitivamente & bestimmt & définitivement & дефинитивно & definito & 분명히 \\
\hline delicious & delicioso, a & köstlich & délicieux & укусно & delizia & 맛있는 \\
\hline democratic & demócrata & Demokratie & démocratique & демократично & democratico & 민주주의 \\
\hline dense & denso, a & dicht & dense & густ & denso & 밀집된 \\
\hline dentist & dentista & Zahnarzt & dentiste & зубар & dentista & 치과의사 \\
\hline depend on & depender de & $\begin{array}{l}\text { darauf } \\
\text { ankom- men }\end{array}$ & dépendre de & зависити од & dipendere & 에 달려있다 \\
\hline
\end{tabular}

\subsection{Purpose of the test}

The purpose of the word recognition test is to examine our initial hypothesis: When a student is confronted with a new linguistic unit for the first time, he/she immediately notices the similarities with the already known unit of the languages he/she is familiar with (Rigbom 2007:9), and takes the first step in learning, by inferring and making a hypothesis about the word meaning/form.

The conclusions are based on the error analysis as we agree with Corder (1967) that errors reflect the creativity of students and the fact that learning is taking place. 


\section{Results}

We categorized students answers into three categories: lack of response, correct answer, and abductive reasoning. The lack of responses is considered as the absence of abductive reasoning. The portion of abductive reasoning in correct answers is unknown since the conclusions are drawn from error analysis. Incorrect answers, as we explained before, are considered as abductive reasoning.

English to Spanish word recognition test

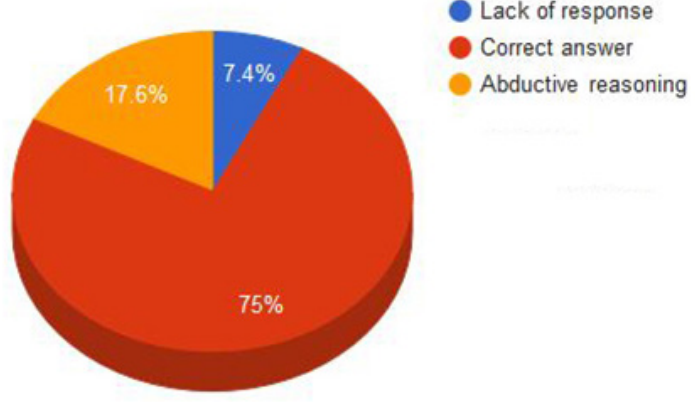

Chart 1. English to Spanish recognition test results in percentage

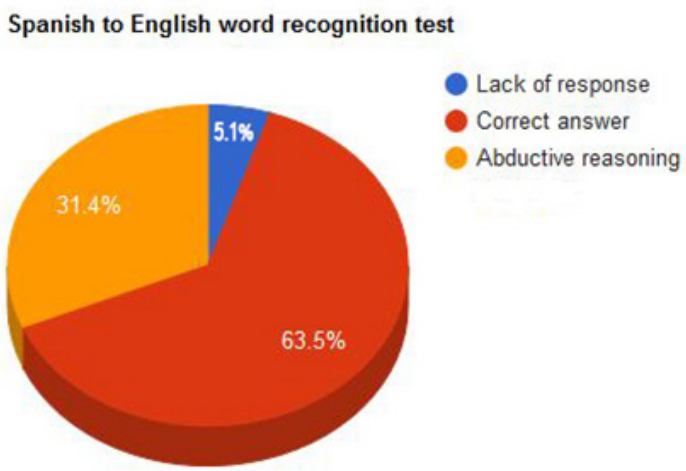

Chart 2. Spanish to English recognition test results in percentage 
ABDUCTIVE REASONING AS A CONSEQUENCE OF TRANSLANGUAGING...

The data analysis ${ }^{2}$ shows that there was some degree of difference between students receptive and productive skills, and, as we expected, the analysis showed better outcomes for the English to Spanish word recognition test (75\% compared with $63.5 \%$ of productive skill). Better results in receptive skills could be understood in light of the fact that productive skills require additional learning of new written patterns in different writing systems (a student may display good receptive skills of the word clown, but produces roughly approximate written form: clauno). In addition, Nation states that receptive use generally gets more practice than productive skills, which can be considered in further instruction planning (Nation 2013: 51).

However, the data analysis demonstrates the students' usage of their multilingual repertoires and tendency to infer the word meaning (31.4\%). It also suggests that they are experimenting with alternative forms of expressions by making approximate forms in the target language (17.6\%).

Of all responses from the two recognition tests, $12.05 \%$ are qualified as lack of responses and this is important for the quantitative analysis. The absence of abductive reasoning might be influenced by the fact that students are frequently hesitant to provide a response when they are not sure of it.

Linguistic interference occurs in the case of English-Spanish Spanish-English false cognates. It is probable that the students respond automatically without critical thinking (more than 88\% translated carpeta as carpet instead of folder; exactly 88\% of English false cognate record to Spanish recordar instead of to remember; 85\% éxito for English exit instead of success). On the other hand, although we did not find the evidence of students' critical thinking, we did find the evidence for interlinguistic transfer - from Italian uscito for Spanish salida or registrar for Spanish recorder and from French sortir for English exit.

As previously mentioned in Table 1 , results from the abductive reasoning are presented and interpreted in the light of exposed

2 We are not analyzing all the answers but only those relevant for this paper. 
theoretical framework: a student from Germany, a Spanish language learner inferred correctly the meaning of the Spanish item danza. The student is confronted with a stimulus danza, he hypothesizes that it could be related to English dance, and he looks for potential grapheme-phoneme correspondences to support and explain his reasoning. Finally, he supports potential rule in Spanish terraza from English terrace. Besides, he supports his finding with knowledge of German language - there is $Z$ in German tanzen! It has to be in Spanish danza as well...

The data analysis reveals the "foreign language effect" (Ringbom 2007: 78). If students perceive L2 (in this study English as the official school language) related to L3 (Spanish, hereby language of instruction), they search for lexical and structural similarities between languages. We were able to find evidence of L2 influence in the item airoport instead of aeropuerto for the English word airport.

Nevertheless, the analysis also reveals that the students rely on their mother tongue and make transfer from languages other than English (German, Italian, French) to coin words in Spanish. All knowledge is valued and it is recognized that languages do not fit into clear bounded entities (Garcia \& Wei 2014: 116).

A closer analysis exposes some original evidence of students using abductive reasoning. On two occasions students gave the translation blog for the Spanish bloque which can be related with interlexical similarity. Also, they offered plant, plane and planet for Spanish planear or best and bestfriend for bestia (for English beast). For English letter students use their international storage email and compensation strategy mensaje. For the same item there is also evidence of plurilingual repertoire usage in attempts of guessing the word form: wordo. English orange has association with Spanish amarillo (yellow) which is not surprising if we consider the memory strategy which involves grouping unknown items with familiar concepts.

An important finding of the study is that students bring the whole of their linguistic and non-linguistic knowledge in order to formulate conclusions. In fact, more than $90 \%$ of all responses for 
ABDUCTIVE REASONING AS A CONSEQUENCE OF TRANSLANGUAGING...

Spanish feliz were correct and the rest of answers very close to the correct response which demonstrates the importance not only of language knowledge, but also of its culture. Students showed capacity to infer the word meaning based on their knowledge of cultures, the worldwide popular song Feliz Navidad and wellknown idiom cumpleaños feliz, which leads to answers happiness, party, happy birthday.

\section{Conclusion}

With the aim of moving towards a multilingual conception of society and education, we investigated plurilingual students in a formal, multicultural context. The purpose was to develop a new understanding of the process of language acquisition. We focused on plurilingual students' performance when engaged in establishing an interlexical similarity between an unknown item and a known one that they already had in mind. This process of searching for interlinguistic similarities and making conclusions requires use of inferencing strategy known as abductive reasoning.

The main objective was to address the role of translanguaging as a pedagogical practice with regard to how students use their plurilingual repertoires, and to encourage them to reach conclusions in accordance with already known linguistic and non-linguistic evidence. Apart from the importance of knowledge of language, the analysis also shows the importance of knowledge of its related culture.

Results from analysis show that our main hypothesis is confirmed: by relying on both plurilingual and pluricultural knowledge, students implement a strategy of abductive reasoning in inferring word meaning and form. Namely, when confronted with a new linguistic item for the first time, they use their plurilingual repertoire and notice the similarities with an already known item of the languages they are familiar with and make the first step in learning - they try to infer the word meaning (31.4\% of all students) and make a hypothesis about the word form (17.6\% of all students).

In light of the analysis and interpretation of results obtained from the students' responses, our study shows a link between the 
role of plurilingualism, translanguaging, and abductive reasoning in language learning. Namely, they share the important concept that all knowledge and all experience of languages contribute to the process of better anticipation and understanding. In interpreting our findings, we have highlighted that by using the strategy of abductive reasoning in learning, students demonstrate their critical thinking skills as well as their originality and creativity in language performance.

The most important finding from a teacher's point of view is that students feel more comfortable in a classroom where the translanguaging approach is used. Accordingly, they feel safe to express themselves freely, using their own creative strategies and drawing conclusions from their entire linguistic repertoire. On one occasion, a student offered the translation please for the word isla. Although we do not correlate this response with a students' ability to draw conclusions from their linguistic repertoire, it reflects their feelings of trust and openness to express themselves freely, an important contribution to students' personal growth and academic development, and absolutely in accordance with the emotional turbulences of their age.

\section{BIBLIOGRAPHY}

Berthele 2011: R. Berthele, On abduction in receptive multilingualism. Evidence from cognate guessing tasks. Applied Linguistics Review, 2, 192-220.

Cenoz 2003: J. Cenoz, The additive effect of bilingualism on third language acquisition: A Review. International Journal of Bilingualism, 7(1), 71-87.

Cenoz 2013: J. Cenoz, Defining multilingualism. Annual Review of Applied linguistics, 33, 3-18.

Corder 1967: S. P. Corder, The significance of learner' errors. International Review of Applied Linguistics in Language Teaching, 5(4), 161-171.

Council of Europe 2001: Council of Europe, Common European Framework of Reference for Languages: Learning, teaching, assessment. Modern Languages Division, Strasbourg: Cambridge University Press.

Cummins 2000: J. Cummins, Language, power and pedagogy: bilingual children in the crossfire. Multilingual Matters LTD. 
Eco 1984: U. Eco, Semiotica e filosofia del linguaggio. Torino: Einaudi. Garcia \& Wei 2014: O. Garcia, L. Wei, Translanguaging, Bilingualism and Education. Palgrave Macmillan Uk.

Gass \& Selinker 1994: S. Gass, L. Selinker, Language transfer in language learning. Amsterdam: John Benjamins.

Herdina \& Jessner 2002: P. Herdina, U. Jessner, A dynamic model of multilingualism. Perspectives of change in psycholinguistics. Clevedon: Multilingual Matters.

Jovanović \& Zečević Krneta 2012: A. Jovanović, G. Zečević Krneta, Abductive reasoning and second language learning. Journal of Language Teaching and Research, 3(2), 306-313.

Martínez 2016: M. Martínez, Tareas con adolescentes, sí o sí. In: Sonia Eusebio at al. (eds.), Enseñar español a niños y adolescentes, Enfoques y tendencias, Barcelona: Difusión, 57-63.

Nation 2013: P. Nation, Learning vocabulary in another language. Cambridge: Cambridge University Press.

Odlin 1989: T. Odlin, Language transfer. Cross-linguistic influence in language learning. Cambridge: Cambridge University Press.

Pierce 1992, 1998: C. S. Pierce, The essential Pierce (2 vols.). Edited by N. Houser, C. Kloesel \& the Pierce Edition Project. Bloomington, IN: Indiana University Press.

Ringbom 2007: H. Ringbom, Cross-linguistic similarity in foreign language learning. Clevedon/Buffalo/Toronto: Multilingual Matters.

Seligman et al. 2016: M. E. P. Seligman, P. Railton, R. F. Baumeister, C. Sripada, Homo prospectus. Oxford University Press.

Steinberg 2013: L. Steinberg, Adolescence. McGrow-Hill Education.

Thagard 2006: P. Thagard, Hot thought: mechanisms and application of emotional cognition. In collaboration with F. Kroon et al. Cambridge, MA: MIT.

Williams 1994: C. Williams, Arfarniad o Ddulliau Dysgu ac Addysgu yng Nghyddestun Addysg Uwchradd Ddwyieithog. [An evaluation of teaching and learning methods in the context of bilingual secondary education]. Unpublished Doctoral Thesis. University of Wales, Bangor. Williams 1996: C. Williams, Secondary education: Teaching in the bilingual situation. In: C. Williams, G. Lewis, C. Baker (eds.), The language policy: Taking stock. Llangefni, UK: CAI, 39-78. 


\section{Snežana Dimitrijević}

\section{ABDUKTIVNO REZONOVANJE KAO REZULTAT TRANSJEZIČKE KOMUNIKATIVNE AKTIVNOSTI U MULTIKULTURNOM FORMALNOM KONTEKSTU}

\section{Rezime}

Cilj ovog rada je da ukaže da je učionica stranog jezika u Internacionalnoj školi multikulturni dinamički prostor koji svojim plurilingvalnim učenicima pruža mogućnost da objedine svoje jezičke kodove koje su ranije upotrebljavali odvojeno i na različitim mestima. Spajajući tako različite dimenzije svojih znanja, iskustava i kognitivnih kapaciteta, učenici prvenstveno uočavaju onaj deo novog ili nepoznatog vokabulara koji ima sličnosti sa njima već poznatim leksemama, prvenstveno sa jedinicama iz maternjeg jezika, ali i sa vokabularom nekog drugog, njima poznatog, jezika. U trenutku detekcije sličnosti između nepoznate reči stranog jezika i poznate reči iz znanog jezika (bilo maternjeg ili nekog drugog), kod učenika se pokreće mentalni mehanizam čiji rezultat je stvaranje pretpostavke o obliku ili značenju date reči. Ovaj metalni mehanizam stvaranja hipoteze naziva se abduktivno rezonovanje.

Osobenost pedagoškog pristupa u okviru predmeta španski jezik u ovoj školi ogleda se u negovanju principa transjezičke komunikativne aktivnosti. To je metod u nastavi novijeg datuma koji jezičku praksu plurilingvala tretira kao jedinstven jezički repertoar u nameri da svaki učenik bude kognitivno, kreativno, kritički i društveno podstaknut u cilju razvoja njihovih komunikativnih i metalnih sposobnosti.

U radu se slede principi kvalitativnog istraživačkog metoda, odnosno analiziraju se i tumače odgovori učenika na osnovu prethodno sakupljenih podataka iz testa prepoznavanja reči. Rezultati istraživanja svedoče da je primena abduktivnog načina razmišlja kod plurilingvalnih učenika u multikulturnom formalnom kontekstu u skladu sa metodom transjezičke komunikativne aktivnosti, odnosno da već razvijene jezičke sposobnosti u dva ili više jezika, samim tim i poznavanje više kultura, pospešuje kritičko razmišljanje i zaključivanje, kao i da stvara prostor za slobodno, originalno i kreativno jezičko ispoljavanje.

Ključne reči: abduktivno rezonovanje, strategije u učenju stranog jezika, višejezičnost, transjezička komunikativna aktivnost, anticipacija, međujezičko zaključivanje. 
ABDUCTIVE REASONING AS A CONSEQUENCE OF TRANSLANGUAGING...

\section{Appendix. A word recognition tests}

\begin{tabular}{|l|l|l|l|}
\hline \multicolumn{1}{|c|}{ español } & \multicolumn{1}{c|}{ English } & \multicolumn{2}{c|}{ español } \\
\hline \multicolumn{2}{|l|}{} & AIRPORT & \\
\hline AVENTURA & & LETTER & \\
\hline SOPORTAR & & ORANGE & \\
\hline PARADA & & TO CAUSE & \\
\hline VASO & & TO RECORD & \\
\hline INMEDIATAMENTE & & FRESH & \\
\hline ISLA & & CLOWN & \\
\hline OCURRIR & & LARGE & \\
\hline BLOQUE & & TO DEFINE & \\
\hline PLANEAR & & ASSISTANT & \\
\hline ESTILO & & EXIT & \\
\hline FELIZ & & AUTHOR & \\
\hline BESTIA & INTRODUCE & \\
\hline SUCEDER & & TOTALY & \\
\hline CARPETA & & TO PROTECT & \\
\hline EXPLORADOR & &
\end{tabular}

